\title{
Seasonal patterns of bacterial production and biomass in intertidal sediments of the western Dutch Wadden Sea
}

\author{
F. C. van Duyl, A. J. Kop \\ Netherlands Institute for Sea Research, PO Box 59, 1790 AB Den Burg, Texel, The Netherlands
}

\begin{abstract}
Methyl- ${ }^{3} \mathrm{H}$ ] thymidine incorporation, bacterial abundance and biomass were measured over 1 yr on interdidal flats in the western Dutch Wadden Sea. Thymidine incorporation and biomass carbon production peaked in March and in mid-late summer with thymidine incorporation rates ranging from 15 to $15390 \mathrm{nmol} \mathrm{l}^{-1}$ wet sediment $\mathrm{d}^{-1}$ in the top $3 \mathrm{~mm}$ of sediment 10.4 to $518 \mathrm{mgC}^{-1}$ wet sediment $\left.\mathrm{d}^{-1}\right)$. Bacterial production was site-specific. The higher bacterial production at one site could be related to higher organic $C$ sedimentation. At most sites bacterial production covaried with particulate organic carbon content and its decomposable fraction in the sediment, suggesting nutrient stress. Covariation of production with bacterial abundance and biomass was not found. The latter variables showed a distinct seasonality with lowest values in spring/summer and highest values in autumn. Regulation of bacterial density appeared to be strongly density-dependent.
\end{abstract}

\section{INTRODUCTION}

A challenge in microbial ecology is the analysis of the role of bacteria in aquatic benthic systems. Sediments represent a complex environment with an array of niches in which bacteria abound, with total numbers per unit volume ca 1000 times higher than in the waterphase (Meyer-Reil 1984). Numerous feeding relationships have been shown to exist in benthic systems (e.g. Fenchel \& Jørgensen 1977, Mann 1982), in which bacteria are utilised by higher trophic levels such as protozoa, meiofauna, and deposit-feeding macrofauna (e.g. Fuhrman \& McManus 1984. Alongi \& Hanson 1985, Hansen et al. 1987, Kemp 1987, Alongi 1988a, Montagna \& Bauer 1988). The potential contribution of bacteria to these fluxes in sedimentary foodwebs is poorly known and has never, as far as we know, been analysed seasonally in intertidal sediments in temperate climates.

In order to determine such a contribution, specific bacterial production measurements are required. In situ bacterial production measurements in sediments were until recently hardly possible because adequate techniques had not been developed. The [methyl ${ }^{3} \mathrm{H}$ ] thymidine method, presently widely used for production measurements in the watercolumn, has now also been developed for use in sediments. Among the first pioneers in this field were Tobin \& Anthony (1978) and Moriarty \& Pollard $(1981,1982)$. Others then followed including Newell \& Fallon (1982), FalIon et al. (1983) and Findlay et al, (1984). Since then thymidine methodology has improved and been applied in several environments (Moriarty 1986). In the present study the latest developments were used.

Measurements were carried out in the western Dutch Wadden Sea, in an estuary which has been subject to extensive ecological studies (for a review see Wolff 1983), although until now the bacteria have received only limited attention. The role of bacteria as minerajizers was estimated in a study on aerobic mineralization in tidal flat sediments by the Wilde \& Beukema (1984), and bacterial activity in the benthic system was studied in terms of sulphate reduction activity (Groenendaal 1975, Vosjan \& Olaniczuk-Neyman 1977).

The aim of the present paper is to describe the seasonal pattern of production of heterotrophic bacteria on intertidal flats in the western Dutch Wadden Sea and to achieve more insight into the size of the C flux into bacterial biomass and into the 'key' parameters which determine bacterial production rates. 


\section{MATERIAL AND METHODS}

Area description and sample procedure. Four study sites were selected on the intertidal flats of the western Dutch Wadden Sea (Fig. 1) and visited about every 2 mo from November 1986 to September 1987, except for the Griend location, which was sampled only in November 1986, April and June 1987. Locations were chosen to represent the most commonly occurring sedimentary habitats covering approximately equal-sized areas.

Some general characteristics of the sampling sites are listed in Table 1. Sediments were 94 to $99 \%$ sand (> $63 \mu \mathrm{m}$ ) with some silt and clay. Particulate organic carbon contents (POC) ranged from 0.6 to $2.9 \mathrm{gC} \mathrm{l}^{-1}$ wet sediment in the surface layer (Etcheber et al. 1988). The elevation of sampling stations ranged from $-25 \mathrm{~cm}$ to $+35 \mathrm{~cm}$ with respect to MTL.

Sediment samples for analysis of bacterial variables and sediment characteristics were collected during low

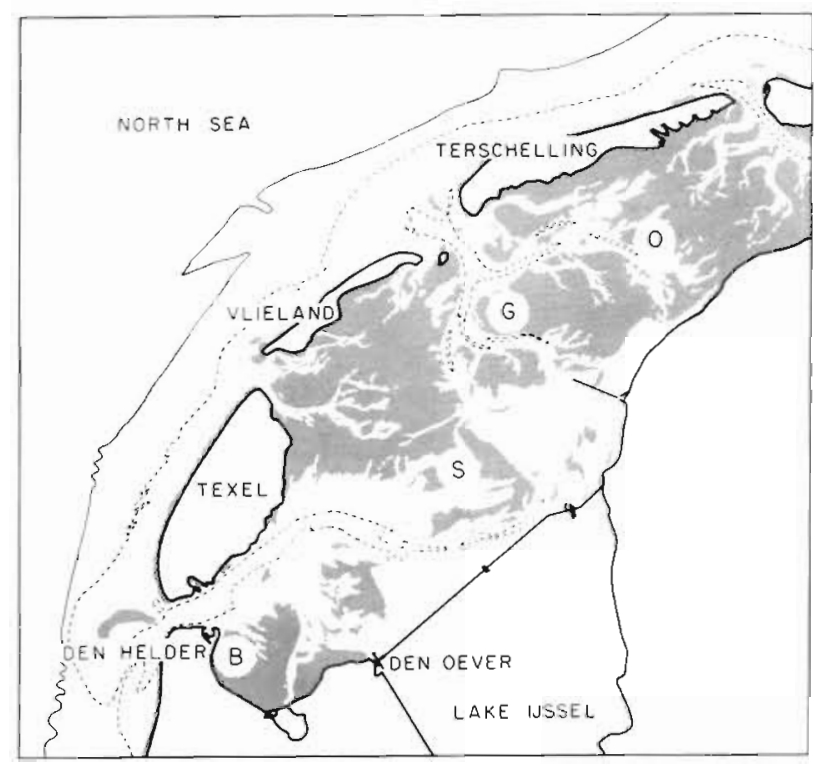

Fig. 1. Location of sampling stations in the western Dutch Wadden Sea. B: Balgzand; S: Scheurrak Omdraai; G: Griend; O: Oost Meep. Intertidal areas are shaded tide on a surface area of ca $25 \mathrm{~m}^{2}$. The temperature in the surface sediment ( 0 to $5 \mathrm{~mm}$ ) was measured (Fig. 2). For bacterial production measurement and bacterial enumeration, ca 15 sediment cores were taken per station with perspex tubes $(2.5 \mathrm{~cm}$ diameter $)$. The top $3 \mathrm{~mm}$ sediment layers of all cores were combined in a glass jar and mixed briefly (up to $1 \mathrm{~min}$ ) with a spatula to obtain a homogeneous slurry. In cases where the slurry was too dry to dispense, seawater collected at the site and filtered through a $0.2 \mathrm{um}$ Acrodisc filter (Gelman) was added, up to $2.5 \%$ of the total slurry volume. At the Griend station deeper layers of the sediment (3 to $11 \mathrm{~mm}$ ) were also sampled. Within $30 \mathrm{~min}$ after collection the slurry was subsampled for thymidine incorporation, bacterial abundance and biomass.

Thymidine incorporation. Bacterial production was estimated from the rate of [methyl- ${ }^{3} \mathrm{H}$ ] thymidine incorporation into DNA. The principles of the method have been described and verified in Fuhrman \& Azam (1980), Moriarty \& Pollard (1981, 1982), Pollard \& Moriarty (1984), and Moriarty (1986). We used a small modification of the technical procedures, which did not invalidate the interpretations of the method (Moriarty 1990).

From the sediment slurry $100 \mu \mathrm{l}$ aliquots were withdrawn with a Gilson pipette $(1 \mathrm{ml})$ equipped with a cutoff disposable tip. Each portion was added to a $100 \mu \mathrm{l}$ solution composed of $25 \mu \mathrm{l}$ aqueous solution containing $25 \mu \mathrm{Ci}$ [methyl- ${ }^{3} \mathrm{H}$ ] thymidine (specific activity 40 to 49 Ci mmol ${ }^{-1}$, Amersham, UK) and $75 \mu$ filtered $(0.2 \mu \mathrm{m})$ seawater from the sampling site, containing different amounts of unlabelled thymidine, 0, 1, 2 or $3 \mathrm{nmol}$, creating a range in final thymidine concentrations of 2.5 to $18 \mu \mathrm{M}$. In this way the isotope dilution (Pollard \& Moriarty 1984) and the bacterial production were always assessed routinely at the same time, because the thymidine concentration to stop de novo synthesis was assumed to vary spatially and temporally. Each assay in the dilution series was done in triplicate, i.e. altogether 12 replicates. Per site, 1 slurry was incubated, usually around noon.

Samples were incubated for 20 min at in situ temperature. The 20 min period was within the linear portion of the incorporation curve (Fig. 3). The incubations

Table 1. Sediment characteristics in the surface layer $(0-3 \mathrm{~mm})$ of intertidal flats partly derived from Etcheber et al. (1988). MTL: mean tide level

\begin{tabular}{|c|c|c|c|c|c|c|c|}
\hline \multirow[t]{2}{*}{ Site } & \multicolumn{2}{|c|}{$\begin{array}{l}\text { Sediment composition, } \\
\text { particle size }(\%)\end{array}$} & \multirow[t]{2}{*}{$\begin{array}{c}\text { Part. org. } \mathrm{C} \\
\text { (g } C \mathrm{l}^{-1} \text { wet sed.) }\end{array}$} & \multirow[t]{2}{*}{$\begin{array}{l}\text { Porosity } \\
(\mathrm{v} / \mathrm{v} \%)\end{array}$} & \multirow[t]{2}{*}{$\underset{(\%)}{\text { Avg. sal. }}$} & \multirow[t]{2}{*}{$\begin{array}{l}\text { Exposure } \\
\text { time }(\mathrm{h})\end{array}$} & \multirow[t]{2}{*}{$\begin{array}{l}\text { MTL } \\
(\mathrm{cm})\end{array}$} \\
\hline & $<63 \mu \mathrm{m}$ & $>63 \mu \mathrm{m}$ & & & & & \\
\hline Balgzand & $0.5-5.7$ & $94.3-99.5$ & $1.953(0.85-2.86)$ & $43-66$ & 23 & 4.5 & -25 \\
\hline Scheurrak & $0.8-1.1$ & $98.9-99.2$ & $1.081(0.64-1.86)$ & $41-43$ & 25 & 4.7 & -25 \\
\hline Griend & $0.4-1.4$ & $98.6-99.6$ & $1.110(0.77-1.38)$ & $41-43$ & 27 & 7.3 & +35 \\
\hline Oost Meep & $1.2-1.8$ & $98.2-98.8$ & $1.124(0.93-1.33)$ & $40-47$ & 27 & 4.3 & -35 \\
\hline
\end{tabular}




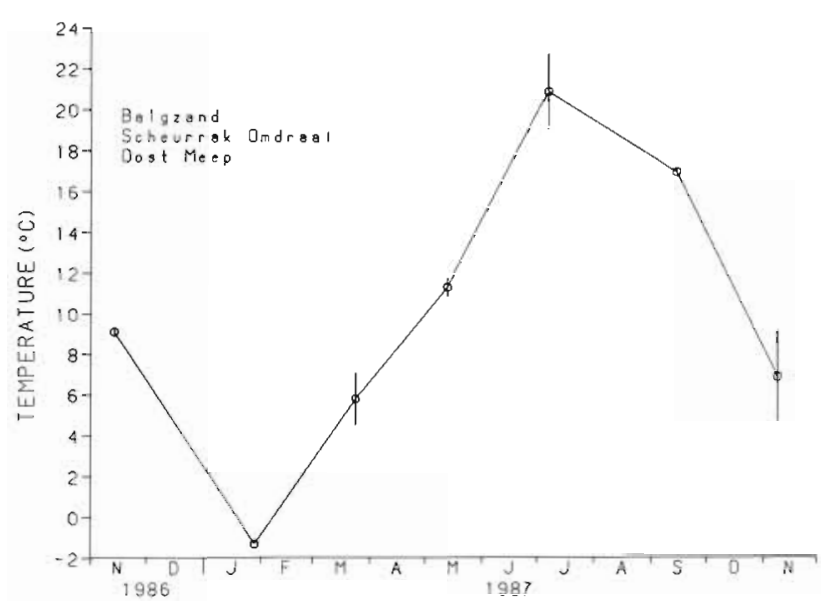

Fig. 2. Seasonal water temperature cycle in surface sediment, combined for the 3 sampling sites (see standard deviations)

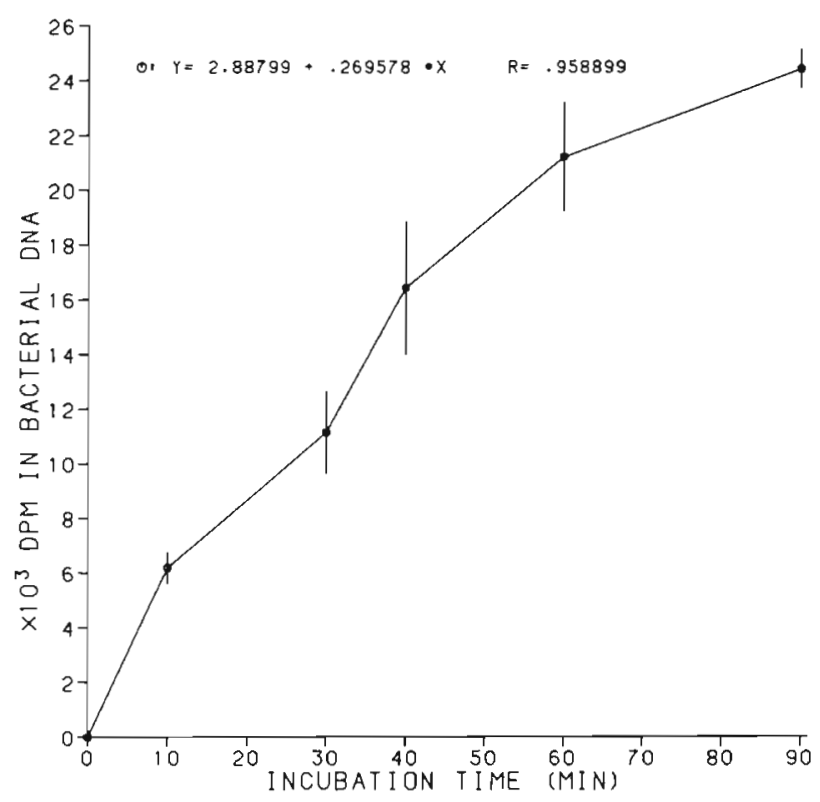

Fig. 3. Time course of ${ }^{3} \mathrm{H}$-thymidine incorporation in disintegrations per min $(\mathrm{dpm})$ at in situ temperature of $9^{\circ} \mathrm{C}$

were stopped with $10 \mathrm{ml} 80 \%$ ethanol containing $2 \%$ $\mathrm{NaCl}$. After shaking, the samples were centrifuged at $2800 \times g$ for ca $60 \mathrm{~min}$ and then decanted. The pellet was resuspended in $80 \%$ ethanol and collected onto wetted $0.4 \mu \mathrm{m}$ polycarbonate filter (Nucleopore $37 \mathrm{~mm}$ ). This filter type was found to be faster and as effective as 0.2 um pore-size polycarbonate filters. Subsequently the sample was washed 4 or 5 times with $2 \mathrm{ml} \mathrm{5 \%}$ ice-cold TCA (trichloroacetic acid) for up to 2 min to precipitate the TCA-insoluble fraction. Afterwards filters were folded and transferred to vials with $2 \mathrm{ml} \mathrm{5 \%} \mathrm{TCA}$ and were heated for $30 \mathrm{~min}$ at $90^{\circ} \mathrm{C}$ to hydrolize DNA. After cooling 0.5 or $1 \mathrm{ml}$ of the hydrolysate was used for counting on the scintillation counter with $10 \mathrm{ml}$ Instagel.
Blank values (stopped at $\mathrm{t}=0$ ) were subtracted from the samples which were stopped at $t=20 \mathrm{~min}$. To convert the thymidine incorporation rate in DNA to bacterial production the following factor was applied: $1 \times 10^{18}$ cells formed for each mol thymidine incorporated in DNA (Bell 1986, Moriarty 1988).

Bacterial abundance, biomass and biomass production. Of the slurry $4.5 \mathrm{ml}$ portions were fixed with $4 \mathrm{ml}$ filtered $(0.2 \mu \mathrm{m})$ seawater and $0.5 \mathrm{ml} 37 \%$ formaldehyde ( $2.1 \%$ final concentration) for bacterial enumeration. In the laboratory $1 \mathrm{ml}$ aliquots of the diluted slurry were dispensed into glass tubes with $0.5 \mathrm{ml}$ distilled water with $\mathrm{NaCl}(30 \%)$ and tetrasodium pyrophosphate (final concentration $10 \mathrm{mM}$ ) and left for 15 to $30 \mathrm{~min}$, to enhance the homogeneous distribution of bacteria. Subsequently, samples were sonicated 3 times for $10 \mathrm{~s}$ at $6 \mu \mathrm{m}$ with a ultrasonic disintegrator (Soniprep, MSE). Cooling was not needed. It was empirically assessed that this treatment achieved the highest recovery of bacteria we could get from the sediment with reproducible results. The 2 -step treatment was derived from Velji \& Albright (1986). Per site and per time, 1 sediment sample was processed.

After proper dilution, dependent on bacterial density, samples were stained with fresh acridine orange solution (final AO concentration $0.01 \%$ ) for 5 min (variant of Hobbie et al. 1977 and Zimmermann et al. 1978). Subsequently the sample was filtered onto a $0.2 \mu \mathrm{m}$ polycarbonate filter (Nuclepore, $25 \mathrm{~mm}$ ), which was stained for $\mathrm{ca} 12 \mathrm{~h}$ in irgalan black solution (100 $\mathrm{mg}$ in 100 to $200 \mathrm{ml} 2 \%$ acetic acid). From each sediment sample one slide was prepared and at least 200 bacteria were enumerated in 10 to 20 microscopic fields. We used a Zeiss epifluorescence microscope with a HBO $50 \mathrm{~W}$ bulb and filterset BP450/490, FT510, LP520 with a magnification of 1250 .

The sizes of at least 100 bacteria were ranked in 13 size classes on the basis of which the mean biovolume per cell per sediment sample was estimated. Subsequently these data were converted into bacterial biomass (in $\mathrm{mgC}^{-1}$ ) as follows: [cells $\mathrm{l}^{-1}$ ] $\times$ [mean

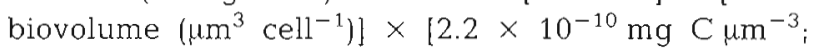
carbon conversion factor of Bratbak \& Dundas 1984]. Bacterial biomass production (in $\mathrm{mg} \mathrm{C}$ ) is then [number of bacterial cells formed per time unit] $\times$ [mean biovolume $\left.\left(\mu^{-3}\right)\right] \times\left[2.2 \times 10^{-10}\right]$. Concurrently Bak \& Nieuwland (1989) measured the abundance and biomass of different size groups of benthic protozoa.

Sediment characteristics. The functional chlorophyll a content (an estimate of the living organic carbon content contained in algae) and the phaeopigment content (an estimate of the algal detritus) were measured according to Holm-Hansen et al. (1965) in the sediment surface layer $(3 \mathrm{~mm})$. In the same layer the porosity of the sediment was determined. The sediment 
Table 2. Dilution of tritiated thymidine by de novo synthesis and/or exogenous and endogenous thymidine expressed as percentage

\begin{tabular}{|lcccccccc}
\hline Site & $\begin{array}{c}1986 \\
\text { Nov }\end{array}$ & $\begin{array}{c}1987 \\
\text { Jan }\end{array}$ & Mar & Apr & May & Jun & Jul & Sep \\
\hline Balgzand & 84 & 0 & 72 & - & 78 & - & 15 & 32 \\
Schleurrak Omdraai & 64 & - & 89 & - & 81 & - & 74 & 50 \\
Griend (day) & - & - & - & 73 & - & 70 & - & - \\
(night) & - & - & - & 55 & - & 54 & - & - \\
Oost Meep & 60 & - & 76 & - & 72 & - & 59 & 77 \\
\hline
\end{tabular}

POC content, its decomposable fraction (as determined according to van Es \& Laane 1982) and the particle size distribution in 2 fractions, $<63 \mu \mathrm{m}$ and $>63 \mu \mathrm{m}$, were measured in the same layer from November 1986 to July 1987 by Etcheber et al. (1988).

Oxygen. The thickness of the oxic zone was measured immediately after sampling with an oxygen electrode (model 760 needle style oxygen electrode, Diamond General Corporation, USA), adapted for use in sediments according to Helder \& Bakker (1985). The electrode was calibrated in $100 \%$ oxygen-saturated seawater and in deoxygenated seawater. With a micromanipulator the electrode was pushed into the sediment until readings from a picoamperemeter connected to the electrode indicated oxygen depletion (Lindeboom \& Sandee 1984, Revsbech \& Jørgensen 1986). The average thickness of the oxic zone was based on measurements in 2 to 5 undisturbed cores per sampling station.

For estimation of bacterial production in the oxic zone, values from the upper $3 \mathrm{~mm}$ layer of the sediment were extrapolated to the average thickness of the oxic zone.

Oxygen consumption of sediments was measured in 2 darkened plexiglass cylindric bell jars (diameter $30 \mathrm{~cm}$ ) in situ on the intertidal flats. The method was adopted from van Es (1977). The bell jars were filled with water collected in the immediate vicinity of the sampling station. Oxygen concentration in the jars was measured after $15 \mathrm{~min}$ preincubation ( $\mathrm{t}=0)$, after $1 \mathrm{~h}(\mathrm{t}=1)$ and after $2 \mathrm{~h}(\mathrm{t}=3)$ with Winkler titrations (Strickland \& Parsons 1972). To express oxygen consumption in terms of carbon a conversion factor of 0.33 was used. For more detailed information refer to van Es (1977).

\section{RESULTS}

\section{Isotopic dilution}

The dilution of the ${ }^{3} \mathrm{H}$-thymidine by de novo synthesis of thymine monophosphate (TMP) is given in Table 2 , separately for each sampling station and sampling date. The dilution varied considerably, both in time and between the various sampling sites. The size of the
Table 3. Thymidine incorporation rate $\left(\mathrm{nmol} \mathrm{l}^{-1}\right.$ wet sediment $\mathrm{d}^{-1}$ ) as measured during daylight and darkness in different depth layers of the sediment at Griend. Bacterial production $\left(\mathrm{mg} \mathrm{C} \mathrm{m} \mathrm{m}^{-2} \mathrm{~d}^{-1}\right)$ in parentheses

\begin{tabular}{|cccccc|}
\hline \multirow{2}{*}{ Depth } & \multicolumn{2}{c|}{ April 1987} & \multicolumn{3}{c|}{ June 1987} \\
& Daylight & Darkness & Daylight & Darkness \\
\hline $0-3 \mathrm{~mm}$ & $186 \pm 33$ & $132 \pm 39$ & $277 \pm 57$ & $358 \pm 74$ \\
& $(18 \pm 3)$ & $(13 \pm 4)$ & $(27 \pm 6)$ & $(34 \pm 7)$ \\
$3-6 \mathrm{~mm}$ & $181 \pm 8$ & $102 \pm 11$ & $342 \pm 54$ & $230 \pm 9$ \\
& $(19 \pm 1)$ & $(12 \pm 1)$ & $(41 \pm 6)$ & $(27 \pm 1)$ \\
$8-11 \mathrm{~mm}$ & - & - & $282 \pm 2$ & $180 \pm 1$ \\
& & & $(32 \pm 0)$ & $(15 \pm 0)$ \\
\hline
\end{tabular}

'pool' diluting the ${ }^{3} \mathrm{H}$-thymidine $(0$ to $4.23 \mathrm{nmol}$ per $200 \mu \mathrm{l}$ sediment slurry) was not correlated to environmental factors such as temperature (Spearman correlation, $\left.r_{\mathrm{s}}=-0.182, \mathrm{n}=21\right)$, organic carbon content $\left(\mathrm{r}_{\mathrm{s}}=\right.$ $-0.288, n=14)$, particle size distribution in the sediment (fraction $<63 \mu \mathrm{m}, \mathrm{r}_{\mathrm{s}}=-0.165, \mathrm{n}=14$; fraction $>63 \mu \mathrm{m}, \mathrm{r}_{\mathrm{s}}=0.033, \mathrm{n}=14$ ), nor to bacterial abundance.

\section{Thymidine incorporation and production}

Rate calculations were corrected for their respective dilutions (sediment 'pool' size + added unlabelled pool size) and extrapolated to rates per day. Extrapolation of 20 min incubations in daylight resulted in slight overestimations of incorporation in April and slight underestimations in June for the Griend data (Table 3). Rates gradually decreased with depth.

Thymidine incorporation rates in the top $3 \mathrm{~mm}$ of sediment varied between locations and ranged over a whole year from 15 to $15390 \mathrm{nmol} \mathrm{l}^{-1}$ wet sediment $\mathrm{d}^{-1}$ at Balgzand, 15 to $1206 \mathrm{nmol} \mathrm{l}^{-1}$ wet sediment $\mathrm{d}^{-1}$ at Scheurrak Omdraai and 15 to $506 \mathrm{nmol} \mathrm{l}^{-1}$ wet sediment $\mathrm{d}^{-1}$ at Oost Meep. At Griend rates were only measured in November, April and June and ranged from 132 to $358 \mathrm{nmol}^{-1}$ wet sediment $\mathrm{d}^{-1}$. Because the variation in thymidine incorporation rates was closely parallelled by biomass production rates, only production rates are further considered. 
Table 4. Summary of 2-way ANOVA of data in Fig. 4, examining the variation of bacterial production in the $3 \mathrm{~mm}$ surface layer of the sediment

\begin{tabular}{|lrrrc|}
\hline Source & df & MS & F & p \\
\hline Site & 2 & 73362 & 160 & $<0.001$ \\
Season (month) & 5 & 18592 & 41 & $<0.001$ \\
Site $\times$ Season & 10 & 29383 & 64 & $<0.001$ \\
Error & 155 & 459 & & \\
\hline
\end{tabular}

Bacterial production varied significantly with location and season (Table 4). Production at the Balgzand site was significantly higher than at the other sites [StudentNewman-Keuls (SNK) test, $p<0.05$ ]. The rates recorded at Scheurrak Omdraai, Oost Meep and Griend were similar, to within one order of magnitude, in similar and adjacent months. Mean bacterial production rate at Balgzand was ca $143 \mathrm{~g} \mathrm{Cm}^{-2} \mathrm{yr}^{-1}$, more than 10 times higher than the annual production recorded at Scheurrak Omdraai $\left(12 \mathrm{~g} \mathrm{Cm}^{-2} \mathrm{yr}^{-1}\right)$ or Oost Meep (11 $\left.\mathrm{g} \mathrm{Cm}^{-2} \mathrm{yr}^{-1}\right)$ in the upper $3 \mathrm{~mm}$ of sediment.

Seasonal patterns of production are shown in Fig. 4. The lowestrate in January, $1 \mathrm{mg} \mathrm{C}^{-2} \mathrm{~m}^{-2} \mathrm{~d}^{-1}$ in the upper $3 \mathrm{~mm}$ of sediment, was measured only at Balgzand (Fig. 4a), but was plotted on the graphs for the other stations (Fig. 4b, c). Scheurrak Omdraai and Oost Meep were inaccessible for our regular research vessel at that time due to heavy ice formation in the western Wadden Sea. We assumed that rates at these low temperatures $\left(-1.3^{\circ} \mathrm{C}\right)$ were comparably low for all locations.

In March and at the end of summer we recorded significantly enhanced production rates (SNK test). The bacterial production peak in March was proportionally most conspicuous at Scheurrak Omdraai and Oost Meep, and was followed by a dip in rates in May. From May to July/September a significant increase in production was found at all stations with a deviating pattern at the Balgzand site. This was mainly due to the outstandingly high rates recorded at Balgzand in July and September with specific growth rates of 0.12 to $0.17 \mathrm{~d}^{-1}$. Patterns of production significantly covaried for the sampling sites Scheurrak Omdraai and Oost Meep.

All production rate estimates may be slight underestimations, because values were not corrected for DNA recovery, which generally exceeds $80 \%$ with this method, according to Moriarty \& Pollard (pers. comm.).

\section{Bacterial abundance and biomass}

Results of the enumeration of benthic bacteria and biomass in the top $3 \mathrm{~mm}$ layer of the sediment are shown in Fig. 5. As expected the patterns of abundance and biomass at each site were broadly similar. This is
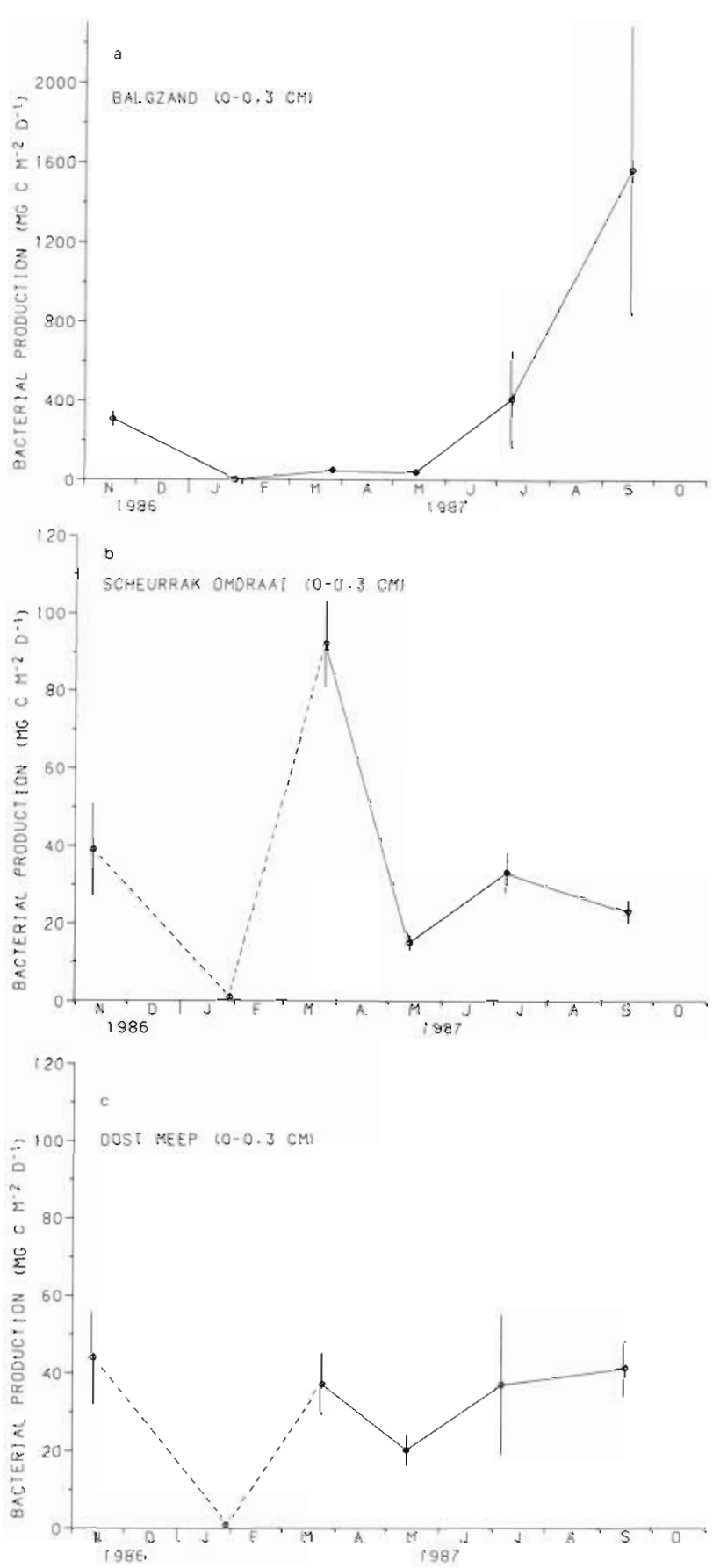

Fig. 4. Seasonal fluctuations in bacterial production. (a) Balgzand; (b) Scheurrak Omdraai (c) Oost Meep

because the mean biovolume of benthic bacteria did not show as much seasonal fluctuation as bacterial density. Average biovolume (not shown) ranged maximally from $0.09 \mu \mathrm{m}^{3}$ (Balgzand, July) to $0.21 \mu \mathrm{m}^{3}$ (Scheurrak Omdraai, November) per cell with the smallest volumes in July at all locations. At Balgzand the biovolume in September was almost double that in July $\left(0.09\right.$ and $0.16 \mathrm{~mm}^{3}$ respectively). Mean annual 

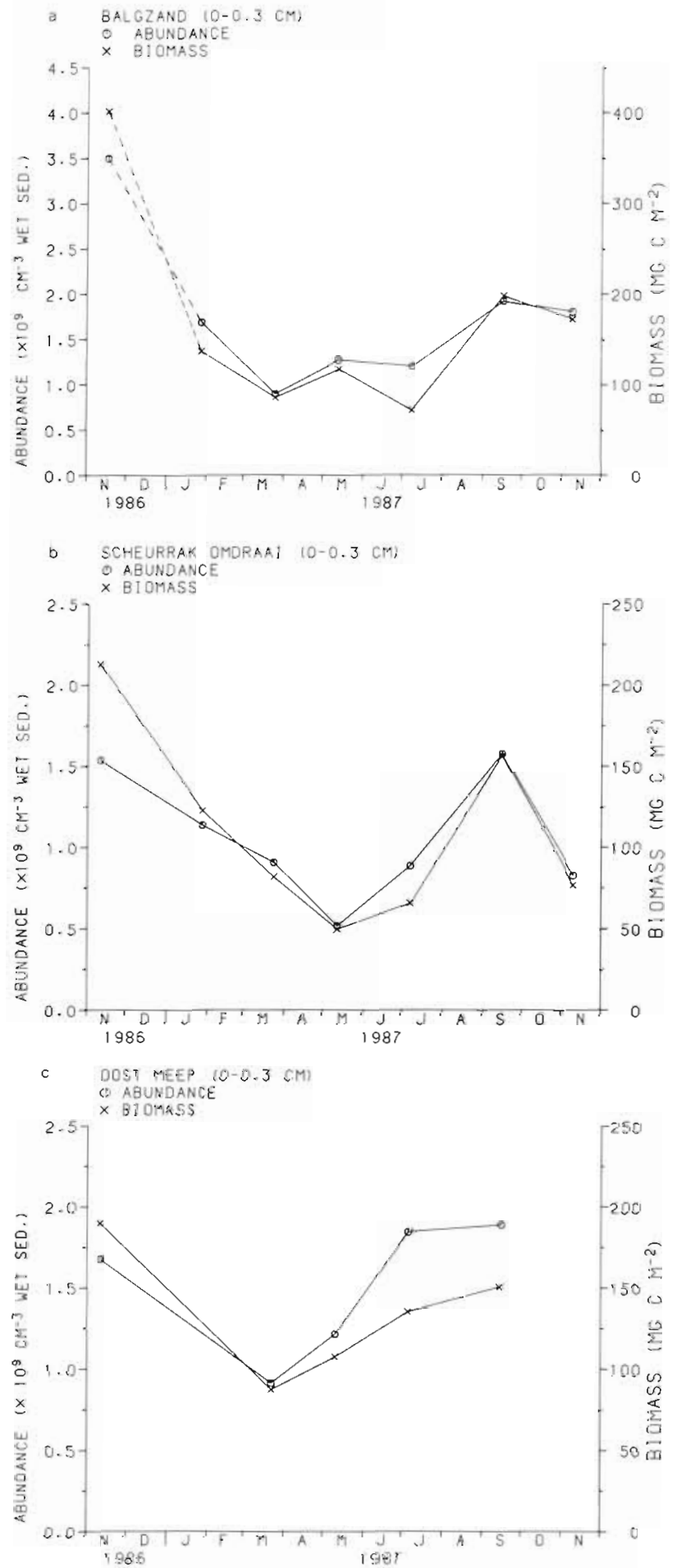

Fig. 5. Seasonal fluctuations in bacterial abundance and biomass. (a) Balgzand; (b) Scheurrak Omdraai; (c) Oost Meep

biovolumes were $0.139 \mu^{3}$ for Balgzand, $0.151 \mu \mathrm{m}^{3}$ for Scheurrak Omdraai and $0.136 \mu \mathrm{m}^{3}$ per cell for Oost Meep.

Numbers varied between 0.52 and $3.50 \times 10^{9} \mathrm{ml}^{-1}$ wet sediment, with lowest numbers from March to May, for all stations, followed by a slight increase later in the season. Biomass dipped in spring and early summer at all 3 locations and remained relatively low during summer. In November 1986 a more silty location was sampled at Balgzand than on subsequent sampling dates in 1987 . In the estimate of yearly average abundance and biomass these data were excluded. The averaged annual bacterial abundance and biomass $\mathrm{ml}^{-1}$ wet sediment in the surface layer of the sediment at Balgzand then amounts to $1.47 \times 10^{9}$ and $44 \mu \mathrm{g} \mathrm{C}$ respectively. At Scheurrak Omdraai $1.06 \times 10^{9}$ cells $\mathrm{ml}^{-1}$ wet sediment were found with a biomass of $38 \mu \mathrm{g} \mathrm{C}$ and at Oost Meep these values were $1.51 \times 10^{9}$ cells $\mathrm{ml}^{-1}$ wet sediment with a biomass of $37 \mu \mathrm{g} \mathrm{C}$.

The magnitude and seasonal pattern of bacterial abundance as well as biomass were not significantly different between stations. Their patterns did not significantly covary with bacterial production.

\section{Oxic zone and oxygen consumption}

The oxic zone varied over the year in thickness from 2 to $12 \mathrm{~mm}$. Year-round the oxic zone was found to be thinnest at the Balgzand site, where it was 2 to $4 \mathrm{~mm}$ thick. The other locations demonstrated much larger fluctuations in thickness (Table 5). Extrapolation (or interpolation f of the measured production in the upper $3 \mathrm{~mm}$ layer of the sediment to the oxic zone, in order to arrive at aerobic bacterial production $\mathrm{m}^{-2} \mathrm{~d}^{-1}$, was justified for the Griend data (Tables 3 and 5). This resulted in annual aerobic bacterial productions of $104 \mathrm{~g} \mathrm{C} \mathrm{m}^{-2} \mathrm{yr}^{-1}$ for Balgzand, $24 \mathrm{~g} \mathrm{C} \mathrm{m}^{-2} \mathrm{yr}^{-1}$ for Scheurrak Omdraai and $19 \mathrm{~g} \mathrm{C} \mathrm{m}^{-2} \mathrm{yr}^{-1}$ for Oost Meep (Table 5).

Oxygen consumptions or $\mathrm{C}$ mineralizations for these locations were 162,76 and $82 \mathrm{~g} \mathrm{C} \mathrm{m}^{-2} \mathrm{yr}^{-1}$ respectively with variations of 27 to $851 \mathrm{mg} \mathrm{C} \mathrm{m}^{-2} \mathrm{~d}^{-1}$ (Fig. 6). In January we succeeded in measuring benthic respiration only at Scheurrak Omdraai due to freezing temperatures. Benthic respiration was significantly correlated with temperature $\left(r_{s}=0.88, n=19, p<0.01\right)$ and bacterial abundance $\left(r_{\mathrm{s}}=0.53, \mathrm{n}=18, \mathrm{p}<0.05\right)$.

\section{Relations of bacterial variables with organic matter and temperature}

Significant covariation of bacterial production with POC and the decomposable POC content in the sediment was found for the pooled data of Scheurrak Omdraai, Griend and Oost Meep $\left(r_{s}=0.67, n=10\right.$, $\mathrm{p}<0.05 ; r_{\mathrm{s}}=0.96, \mathrm{n}=7, \mathrm{p}<0.05 ;$ Fig. 7 ). Such correlations were not established for Balgzand. Here the seasonal pattern of bacterial production was best 
Table 5. Seasonal variations in thickness of oxic zone of the sediment in $\mathrm{mm}$ with extrapolated aerobic bacterial productions ( $\mathrm{mg} \mathrm{Cm} \mathrm{Cm}^{-2} \mathrm{~d}^{-1}$ ) and averaged annual production, $\mathrm{C}$ demand (growth efficiency $50 \%$ ) and mineralization

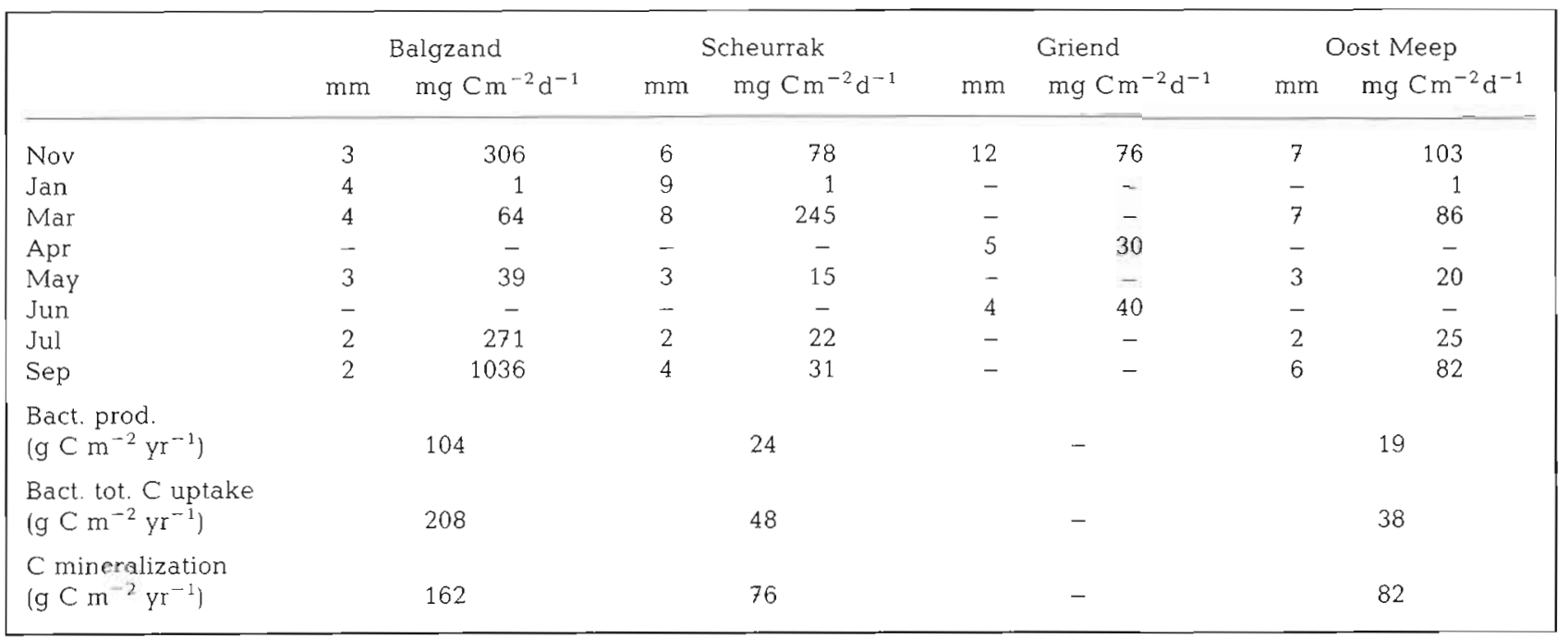

reflected by temperature $\left(r_{s}=0.77, n=6, p<0.1\right)$. At the other sites bacterial production did not covary with temperature $\left(r_{\mathrm{s}}=0.22, \mathrm{n}=16\right)$.

The functional chlorophyll a content in the upper layer of the sediment was on an annual basis equal for all stations, 4.2 to $6.5 \mu \mathrm{g} \mathrm{cm}^{-3}$ wet sediment (t-test) with the highest value in May at Balgzand and in September at Scheurrak Omdraai and Oost Meep. Bacterial variables were not related to sediment chlorphyll a content. The annually averaged phaeopigment content was higher at Balgzand $\left(6.8 \mu \mathrm{g} \mathrm{cm}^{-3}\right.$ wet sediment) than at Oost Meep $\left(4.0 \mu \mathrm{g} \mathrm{cm} \mathrm{cm}^{-3}\right.$ wet sediment; t-test, $\mathrm{p}<0.1$ ) and for both these sites significantly higher than at Scheurrak Omdraai $\left(1.9 \mu \mathrm{g} \mathrm{cm}^{-3}\right.$ wet sediment; t-test, $p<0.05)$. Variations in chlorophyll $a$ and phaeopigment roughly covaried, both showing irregular seasonal patterns.

Bacterial abundance was significantly related to POC and phaeopigment content in the sediment for the pooled data of all stations. Bacterial biomass showed a significant covariation with the phaeopigment content in the sediment only $\left(\mathrm{r}_{\mathrm{s}}=0.483, \mathrm{n}=17, \mathrm{p}<0.05\right)$.

\section{DISCUSSION}

\section{Methodological considerations}

Although addition of labelled precursors to sediment slurry induces greater disturbance artifacts than injection techniques (e.g. Findlay et al. 1985, Dobbs et al. 1989), we chose slurrying in our set up. Moriarty et al. (1985a) demonstrated that disturbance introduced by slurrying did not influence thymidine incorporation rates in DNA in short 15 min incubation experiments. This was recently confirmed by Dobbs et al. (1989) in much longer experiments (up to $5 \mathrm{~h}$ ). In slurries the label is more evenly distributed at the onset of incubations than in injected samples. In addition it is more efficient to incubate slurries, which can be used in small volumes, than undisturbed sediment samples considering the high concentrations of ${ }^{3} \mathrm{H}$-thymidine (expensive) required in sediments.

The conversion factor of thymidine incorporation to bacterial production cannot be determined in sediments without major disturbance of the natural environment. So this factor has to be chosen on a theoretical basis or has to be derived experimentally in natural watersamples. In the present study we adopted the value of $1 \times 10^{18}$ cells formed per mol thymidine incorporated, which approaches the mean in the range of independent determinations (Kirchman et al. 1982, Kirchman \& Hoch 1988) and theoretical considerations (Fuhrman \& Azam 1980, Moriarty 1988).

For the theoretical background to the isotopic dilution approach and its verification we refer to Moriarty \& Pollard (1981), Moriarty (1984), Pollard \& Moriarty (1984) and Bell (1986). The 'pool' of exogenous and endogenous thymidine and thymine precursors in sediments, which effectively dilutes the added pool, varied year-round from 0 to $4.23 \mathrm{nmol} 200 \mathrm{Ml}^{-1}$ sediment slurry, spatially as well as temporally (Table 2), when using the indicated fixed range of added thymidine concentrations for the incubations. The added thymidine of up to $3.6 \mathrm{nmol} 200 \mathrm{\mu l}^{-1}$ sediment slurry was for most incubations apparently insufficient to stop isotopic dilution, despite the fact that this concentration was considerably higher than those used by others in marine and 


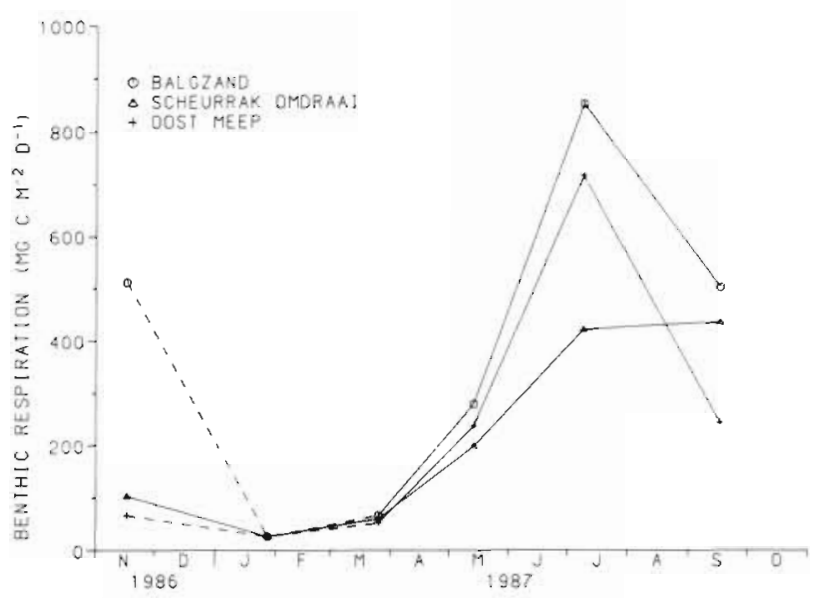

Fig. 6. Seasonal fluctuations in benthic $\mathrm{C}$ mineralization as measured with bell jars at Balgzand, Scheurrak Omdraai and Oost Meep

fresh water sediments (e.g. Fallon et al. 1983, Findlay et al. 1984, Bell \& Ahlgren 1987). This might indicate that the thymidine actually available for bacteria in our sediments was much lower than the total amount of thymidine added and as such might have been too low to block de novo synthesis of TMP by bacteria. Physicochemical characteristics such as the complexation of thymidine molecules with high molecular weight organic molecules or metals might influence the availability of thymidine in the sediment.

\section{Spatial variation in production and biomass}

Bacterial production in intertidal surface sediments of the western Dutch Wadden Sea fits well in the range of bacterial productions as measured in other sedimentary environments (Table 6). The highest bacterial productions as recorded at the Balgzand site were, as far as we know, only equalled by production in tropical mangrove sediments (Queensland, Australia; Boto et al. 1989) and in the sediment of a hypereutrophic lake in Sweden (Bell \& Ahlgren 1987).

Comparison of our data between sampling sites show that average bacterial production in the surface layer at Oost Meep and Scheurrak Omdraai was of a similar order of magnitude, 11 to $12 \mathrm{~g} \mathrm{C} \mathrm{m}^{-2} \mathrm{yr}^{-1}$ in the upper $3 \mathrm{~mm}$ surface layer and 19 and $24 \mathrm{~g} \mathrm{C} \mathrm{m}^{-2} \mathrm{yr}^{-1}$ respectively in the oxic zone. The few production data available for the Griend site fit well in this range. The $3 \mathrm{~h}$ longer emersion time of this site (see Table 1) apparently did not have a noticeable influence on bacterial production. The Balgzand site is significantly more productive, $143 \mathrm{~g} \mathrm{C} \mathrm{m}^{-2} \mathrm{yr}^{-1}$ in the upper $3 \mathrm{~mm}$ layer and $104 \mathrm{~g} \mathrm{C} \mathrm{m}^{-2} \mathrm{ys}^{-1}$ in the oxic zone, than the other sampling sites in the western Dutch Wadden Sea. The

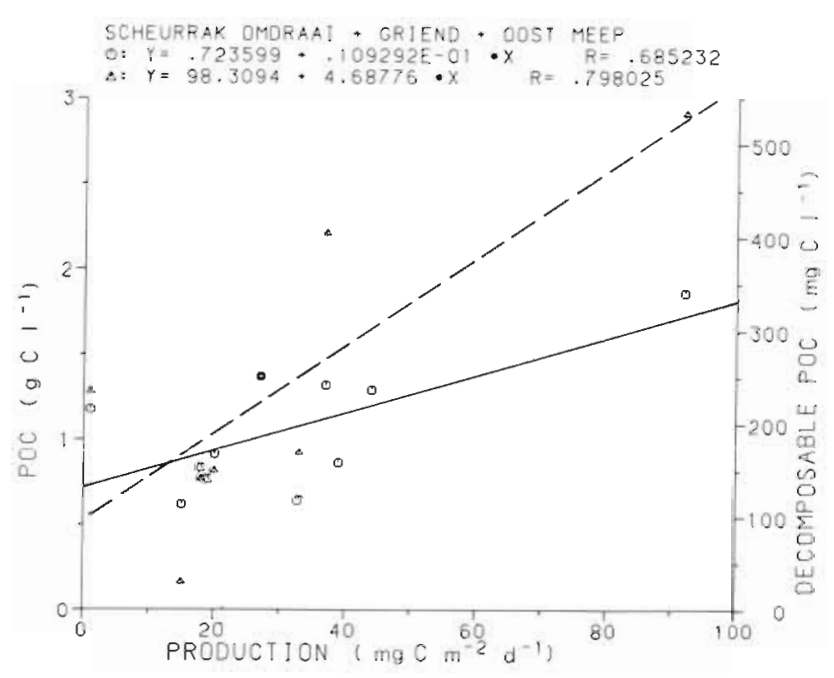

Fig. 7. Relation between POC, its decomposable fraction and bacterial production for pooled data of Scheurrak Omdraai, Griend and Oost Meep. (O) POC, solid line; ( $\triangle$ ) decomposable POC, dashed line

difference cannot be related to temperature, porosity or particle size distribution, for which aspects only modest differences exist between sampling sites (Fig. 2; Table 1); moreover bacterial production rates did not align with these parameters.

The higher production suggests an overall higher nutrient supply to the bacteria at the Balgzand site, indirectly implicating a higher total $\mathrm{C}$ input into the benthic system (assuming an equal average growth efficiency for benthic bacteria in the different sites). Assuming a steady state between C-input and C-loss by mineralization on an annual basis (van Es 1982), the 2 times higher benthic mineralization rate at the Balgzand site than at the other sites (Table 5) supports the suggested higher $\mathrm{C}$-input. The extra Cinput could not be attributed to higher biomasses of phytobenthos (measured as chlorophyll a), which were on an annual basis comparable at all sampled sites. This implies that benthic primary production at stations is comparable considering the correlation between chlorophyll $a$ and production on an annual basis (Cadée \& Hegeman 1977). The year-round higher phaeopigment/chlorophyll a ratio of the sediment at Balgzand as well as the higher POC content support the conclusion that the net sedimentation of organic matter at the Balgzand site is higher than at the other sampling sites, resulting in overall higher bacterial production.

Average bacterial abundance and biomass over 1 yr were approximately the same for all stations, regardless of annual production rates. This indicates that the removal or disappearance of bacteria or bacterial biomass equals production on an annual basis.

To arrive at the annual carbon demand of aerobic 
heterotrophic bacteria on intertidal flats in the western Dutch Wadden Sea we assumed that the bacterial production as measured at the Balgzand site is representative for $1 / 3$ of the total area and the production as measured at Scheurrak Omdraai and Oost Meep covers the remaining area. With an assumed average growth efficiency of aerobic bacteria in the sediment of $50 \%$ (Moriarty et al. 1985b), we end up with an average carbon demand of ca $100 \mathrm{~g} \mathrm{C} \mathrm{m}^{-2} \mathrm{yr}^{-1}$ in the oxic zone of the sediment, with $208 \mathrm{~g} \mathrm{C} \mathrm{m}^{-2} \mathrm{yr}^{-1}$ at the Balgzand site, $48 \mathrm{~g} \mathrm{C} \mathrm{m}^{-2} \mathrm{yr}^{-1}$ at Scheurrak Omdraai and $38 \mathrm{~g} \mathrm{C} \mathrm{m}^{-2} \mathrm{yr}^{-1}$ at Oost Meep. The bacterial $\mathrm{C}$ demand exceeds the annual mineralization at the Balgzand site $(128 \%)$. At the other sites the $\mathrm{C}$ demand of bacteria in the oxic zone amounts to 50 to $60 \%$ of the mineralization (Table 5). The average $\mathrm{C}$ uptake of aerobic heterotrophic bacteria in the intertidal flats fits well into the carbon budget of the western Dutch Wadden Sea as presented in the Report on the Ecosystem model of the western Dutch Wadden Sea (Anonymous 1988).

\section{Seasonal variations in production and biomass}

Bacterial production exhibited significant seasonal variations. Patterns are characterized by a significant increase in early spring (March) at Scheurrak Omdraai and Oost Meep, a dip in May and a significant mid/late summer peak/increase at all sites followed by a

Table 6 . Overview of bacterial production rates as measured in marine and fresh water sediments

\begin{tabular}{|c|c|c|c|}
\hline Environment sediment type & Depth $(\mathrm{cm})$ & Production ( $\mathrm{mg} \mathrm{C} \mathrm{m} \mathrm{m}^{-2} \mathrm{~d}^{-1}$ ) & Prod. normalized to $3 \mathrm{~mm}$ \\
\hline \multicolumn{4}{|c|}{ Tropical mangrove (NE Autralia) } \\
\hline Boto et al. (1989) & $0-1$ & $900-4100$ & $270-1230$ \\
\hline Alongi (1988a) & $0-5$ & $45-1725$ & 2.7-104 (29 annual mean) \\
\hline Alongi (1988b) & $0-2$ & $200-5100$ & $30-765$ \\
\hline Seagrass beds & $0-0.3$ & $15 \pm 7$ (aerobic) & $15 \pm 7$ (annual mean) \\
\hline Moriarty et al. (1984) & $0.3-4$ & $18 \pm 5$ & \\
\hline Moriarty \& Pollard (1982) & $0-0.3$ & 43 (aerobic) & \\
\hline \multirow{2}{*}{ Moriarty $(1986)$} & $0-1$ & 216 & \multirow{2}{*}{$\begin{array}{l}65 \text { (sand bank) } \\
55 \text { (Halodule sed) }\end{array}$} \\
\hline & $0-2$ & 182 & \\
\hline \multicolumn{4}{|c|}{ Hypersaline lagoon (W Australia) } \\
\hline \multirow{3}{*}{ Moriarty (1982) } & $0-0.3$ & $77-120$ & $77-120$ \\
\hline & $0-2$ & 103 & (microbial mat) \\
\hline & $0-2$ & 53 & 8 (subtidal) \\
\hline \multicolumn{4}{|l|}{ Coral reef (NE Australia) } \\
\hline Hansen et al. (1987) & $0-1$ & $29-278$ & $9-84$ \\
\hline \multirow{4}{*}{ Moriarty et al. (1985b) } & & 20 & \multirow{4}{*}{$\begin{aligned} & 15 \text { (reef flat, summer) } \\
& 59 \text { (seagrass, summer) } \\
& 1 \text { (beach, summer) } \\
& 90-143 \quad \text { (flat, winter) }\end{aligned}$} \\
\hline & $0-0.4$ & 78 & \\
\hline & & 1 & \\
\hline & & $120-190$ & \\
\hline \multicolumn{4}{|l|}{ River sediments (Georgia, USA) } \\
\hline \multirow[t]{2}{*}{ Findlay et al. (1984) } & \multirow[t]{2}{*}{$0-1$} & 0.96 & \multirow{2}{*}{$\begin{aligned} 0.3 & \text { (sand) } \\
27.4 & \text { (backwater) }\end{aligned}$} \\
\hline & & 91.2 & \\
\hline Findlay \& Meyer (1984) & $0-1$ & 2.7 & (annual basis) \\
\hline Leaf material & $0-1$ & 2.2 & (annual basis) \\
\hline \multicolumn{4}{|c|}{ Coastal zone sediments (off Georgia) } \\
\hline \multirow[t]{4}{*}{ Fallon et al. (1983) } & $0-25$ & 210 & 2.5 (mud flat) \\
\hline & & 810 & $9.7 \quad(0.25 \mathrm{~km}$ off $)$ \\
\hline & & 330 & $4.0 \quad(6 \quad \mathrm{~km}$ off $)$ \\
\hline & & 100 & $1.2 \quad 15$ \\
\hline \multicolumn{4}{|c|}{ Intertidal sand beach (Oregon, USA) } \\
\hline Kemp (1987) & $0-1.5$ & 55 & 1.1 \\
\hline \multicolumn{4}{|l|}{ Shallow coastal zone (Germany) } \\
\hline Meyer-Reil et al. (1980) & $0-0.7$ & 43 & 18.4 \\
\hline Hypereutrophic lake (Sweden & & & \\
\hline Bell \& Ahlgren (1987) & $0-2$ & $160-15200^{\mathrm{d}}$ & $24-2280$ \\
\hline Intertidal flats (Nethlerlands) & & & \\
\hline This paper & $\begin{array}{l}0-0.3 \\
0-0.3\end{array}$ & $\begin{array}{l}\text { (Balgzand) } \\
\text { (Scheurrak) }\end{array}$ & $\begin{array}{rr}1-1554 & \text { (390 ann. mean) } \\
1-\quad 92 & \text { (33 ann. mean) }\end{array}$ \\
\hline & $0-0.3$ & (Oost Meep) & $1-44 \quad$ (30 ann. mean) \\
\hline
\end{tabular}


gradual decrease to winter values. A comparable pattern was found in sediments in the Kiel Bight in Germany, which was attributed to major sedimentation events (Meyer-Reil 1987).

Variations in bacterial production year-round appear to be mainly controlled by factors related to the availability of food at most of our sampling sites. This was supported by the significant correlation of POC and its decomposable fraction with bacterial production as found for the pooled data of the Oost Meep, Griend and Scheurrak Omdraai sites (Fig. 7). Relations between bacterial production and organic matter have been assessed more often in sediments (e.g. Cole et al. 1988) and point to energy limitation of bacterial production, notwithstanding the considerable amounts of organic $\mathrm{C}$ which are often present in sediments.

However, this organic matter consists mainly of refractory material not readily available to bacteria. The decomposable fraction of POC addressed in this study reflects potentially available organic matter, which mainly consists of biomass or organisms smaller than $1 \mathrm{~mm}$ that were killed in the analysis, considering the methods used (Etcheber et al. 1988). The assumption that the amount of decomposable organic matter aligns with the biomass present in Etcheber's assays implicates that we found a correlation between bacterial production and benthic biomass in the size class smaller than $1 \mathrm{~mm}$. At Balgzand this correlation was not found. Here the production pattern aligned with temperature. The higher organic material sedimentation at Balgzand apparently saves the bacteria from substrate limitation for most of the year.

Bacterial production was not correlated to benthic $\mathrm{C}$ respiration. This is not surprising because bacteria tend to respond within days to a sedimentation event (Graf 1987), while benthic respiration is always closely coupled to temperature following a predictable pattern (this paper, van Es 1982).

The patterns in bacterial production can be explained from different events which take place in the system annually. Each year in March/April a decline of suspended matter in the watercolumn occurs (Postma 1954, 1982, Postma \& Rommets 1970), which tends to be stronger after severe winters with ice (Cadée 1982 . Anonymous 1988) as in 1987. The suspended material probably settles on the bottom and part of it may form a food source for microbes in spring. In the same period the first primary production maximum in the watercolumn usually occurs (Postma \& Rommets 1970, Cadée \& Hegeman 1974a, 1977, Veldhuis et al. 1988), rapidly increasing the amount of $\mathrm{POC}$ and DOC in the watercolumn and sedimentation of fresh algal material. It is probable that these events combined or separately are related to the high bacterial production in early spring.
The POC content and the decomposable POC content in the sediment indeed increased considerably from January to March at least at Scheurrak Omdraai and Oost Meep (Etcheber et al. 1988). The supply of organic matter apparently reanimated the bacterial production in spring.

Reinforcement of the bacterial production from January to March did not result in increasing bacterial abundance and biomass. On the contrary, bacterial abundance and biomass decreased over this period. According to Meyer-Reil (1983) strong seasonal variations in benthic bacterial populations can also be traced back to effects of ecological situations such as the spring development of the benthic fauna in the western Kiel Bight. He attributed the decrease of bacterial biomass in spring to such an event. This explanation might also be valid for the decrease in bacterial biomass during this time in the western Dutch Wadden Sea. Protozoa for instance might have been partly responsible for the high mortality rate of bacteria at that time. Protozoa reached peak abundances in March in the sediment (Bak \& Nieuwland 1989). Like Meyer-Reil (1983) we recorded a decrease in mean biovolume per bacterial cell in spring, which might have been due to selective grazing by bacterivores.

The dip in bacterial production in May is difficult to account for. Benthic primary production on intertidal flats in the Wadden Sea usually peaks in May/June according to Cadée \& Hegeman (1974b, 1977). Our chlorophyll a data did not correspond to this pattern, except at Balgzand. At Scheurrak Omdraai and Oost Meep peak values in chlorophyll a occurred in September. Correlations between bacterial production and chlorophyll a were not found in the present study. Such correlations are well known in the watercolumn of estuarine systems (Malone et al. 1986, van Duyl \& Kop 1988, Kirchman \& Hoch 1988).

The subsequent increase in bacterial production in summer coincided with the temperature increase from 10 to $18^{\circ} \mathrm{C}$. This temperature rise enhances the activity of the whole benthic community as reflected by community respiration. The carbon flux to bacteria might be regulated in this period by the activity of higher trophic levels. Bacterial production at Balgzand remained high in late summer, probably due to the increased fresh water discharges at Den Oever in September supplying the Balgzand with allochthonous organic matter. It is clear that the specific sources of the food supply to the benthic bacteria could not be identified.

Bacterial abundance and biomass did not covary with bacterial production measurements such as observed in the watercolumn (van Duyl \& Kop 1988), but exhibited a different seasonality with relatively 
high values in autumn and relatively low values in spring and summer. Compared to amplitudes in the variation of bacterial production, amplitudes in the variation of bacterial abundance and biomass were small. This implies a continuous removal or degradation of microbial cells, which must approximately equal the production. The regulation of bacterial numbers in sediments is apparently more density-dependent than in the waterphase. Alongi (1988b) attributed the regulation of bacterial numbers primarily to physicochemical factors, tidal flushing and exposure, while he could not assess trophic relations. The seasonal pattern of bacterial production we found was closely resembled by the variations of nanoflagellates as measured concurrently by Bak \& Nieuwland (1989). Increases and peaks in bacterial production were evidently parallelled by protozoan numbers, particularly at Oost Meep and Scheurrak Omdraai. This might indicate that bacteriovory by protists plays an important role in the regulation of bacterial density in intertidal sediments.

\section{CONCLUSIONS}

We showed that application of the thymidine method to intertidal sediments yielded consistent and interpretable results. Bacterial production was site-specific and exhibited seasonality. At 2 sites (Scheurrak Omdraai and Oost Meep) the seasonal patterns were comparable and were related to seasonal variations in substrate availability. The Balgzand site showed a distinct seasonal pattern, which was broadly reflected by temperature. The higher bacterial production rates at Balgzand were due to higher $\mathrm{C}$-input there as compared to the other stations.

Patterns of bacterial production did not covary with bacterial density and biomass. On the contrary, these variables showed a distinct seasonal pattern and were found in comparable orders of magnitudes at the different sampling sites. The regulation of bacterial density in these sediments appears to be density-dependent.

Acknowledgements. Special thanks are due to D. J. W. Moriarty, who introduced us to the thymidine method for sediments and stimulated us to use his technical procedures on Wadden Sea sediment. Clarifying discussions with him and P. C. Pollard contributed to the synthesis of this paper Their hospitality during the first author's stay in Queensland (Australia) is greatly appreciated. We are grateful to H.J. Lindeboom, D.J.W. Moriarty and other reviewers for careful reading and constructive criticism of the manuscript. Without the cooperation of Rijkswaterstaat (Harlingen), which put the MS 'Heffesant' and its helpful crew at our disposal, this project would not have been realized. This is publication no. 6 of the project 'Applied Scientific Research', Netherlands Institute for Sea Research.

\section{LITERATURE CITED}

Alongi, D. M. (1988a). Microbial-meiofaunal interrelationships in some tropical intertidal sediments. J. mar. Res. 46 : 349-365

Alongi, D. M. (1988b). Bacterial productivity and microbial biomass in tropical mangrove sediments. Microb. Ecol. 15: $59-79$

Alongi, D. M., Hanson, R. B. (1985). Effect of detritus supply on trophic relationships within experimental benthic foodwebs. II. Microbial responses, fate and composition of decomposing detritus. J. exp. mar. Biol. Ecol. 88: 167-182

Anonymous (1988). Ecosysteemmodel van de westelijke Waddenzee. EMOWAD I. Nederlands Instituut voor Onderzoek der Zee 1988. NIOZ-Rapport 1988-1

Bak, R. P. M., Nieuwland, G. (1989). Seasonal fluctuations in benthic protozoan populations at different depths in marine sediments. Neth. J. Sea Res. $24: 37-44$

Bell, R. T (1986). Further verification of the isotope dilution approach for estimating the degree of participation of $\left[{ }^{3} \mathrm{H}\right]$ thymidine in DNA synthesis in studies of aquatic bacterial production. Appl environ. Microbiol. 52: 1212-1214

Bell, R. T., Ahlgren, I. (1987). Thymidine incorporation and microbial respiration in the surface sediment of a hypereutrophic lake. Limnol. Oceanogr. 32: 476-482

Boto, K. G., Alongi, D. M., Nott, A. L. J. (1989). Dissolved organic carbon-bacterial interactions at sediment-water interface in a tropical mangrove system. Mar. Ecol. Prog. Ser. 51: 243-251

Bratbak, G., Dundas, I. (1984). Bacterial dry matter content and biomass estimations. Appl. environ. Microbiol. 48: $755-757$

Cadée, G. C. (1982). Tidal and seasonal variation in particulate and dissolved organic carbon in the western Dutch Wadden Sea and Marsdiep tidal inlet. Neth. J. Sea Res. 15: 228-249

Cadée, G. C., Hegeman, J. (1974a). Primary production of the benthic microflora living on tidal flats in the Dutch Wadden Sea. Neth. J. Sea Res. 8: 260-291

Cadée, G. C., Hegeman, J. (1974b). Primary production of phytoplankton in the Dutch Wadden Sea. Neth. J. Sea Res. 8: $240-259$

Cadée, G. C., Hegeman, J. (1977). Distribution of primary production of the benthic microflora and accumulation of organic matter on a tidal flat area, Balgzand, Dutch Wadden Sea. Neth. J. Sea Res. 11: 24-41

Cole, J. J., Findlay S., Pace, J. L. (1988). Bacterial production in fresh and salt water ecosystems: a cross-system overview. Mar. Ecol. Prog. Ser. 43: 1-10

Dobbs, F. C., Guckert, J. B., Carman, K. R. (1989). Comparison of three techniques for administering radiolabeled substrates to sediments for trophic studies: incorporation by microbes. Microb. Ecol. 17.237-250

Duyl, F. C. van, Kop, A. J. (1988). Temporal and lateral fluctuations in production and biomass of bacterioplankton in the western Dutch Wadden Sea. Neth. J. Sea Res. 22: $51-68$

Es, F. B. van (1977). A preliminary carbon budget for a part of the Ems estuary: The Dollard. Helgoländer wiss. Meeresunters. 30: 283-294

$E_{5}, F . B$. van (1982). Some aspects of the flow of oxygen and organic carbon in the Ems-Dollard estuary. Boede Publications 5. Ph. D. thesis, State University, Groningen

Es, F. B., Laane, R. (1982). The utility of organic matter in the Ems-Dollard estuary. Neth. J. Sea Res. 16: 300-314

Etcheber, H., Laane, R., Lin, R. G., Kloosterhuis, R. (1988). Degradability of sedimentary organic matter in estuarine 
and coastal environment. Rijkswaterstaat. Ministry of Transport and Public Works. Tidal Water Division. The Hague, Netherlands GWAO-88.024

Fallon, R. D., Newell, S. Y., Hopkinson, Ch. S. (1983). Bacterial production in marine sediments: will cell-specific measures agree with whole system metabolism? Mar. Ecol. Prog. Ser. 11: 119-127

Fenchel, T M., Jørgensen, B. B. (1977). Detritus food chains of aquatic ecosystems: the role of bacteria. In: Alexander, $M$. (ed.) Advances in microbial ecology 1 Plenum Press, New York, p. 1-58

Findlay, S. E. G., Meyer, J. L. (1984). Significance of bacterial biomass and production as an organic carbon source in lotic detrital systems. Bull. mar. Sci. 35: 318-325

Findlay, S. E. G., Meyer, J. L., Edwards, R. T (1984). Measuring bacterial production via rate of incorporation of $\left.{ }^{3} \mathrm{H}\right]$ thymidine into DNA. J. microbiol. Meth. 2: 57-72

Findlay, R. H., Pollard, P. C., Moriarty, D. J. W., White, D. C (1985). Quantitative determination of microbial activity and community nutritional status in estuarine sediments: evidence for a disturbance artifact. Can. J. Microb. 31 : $493-498$

Fuhrman, J. A.., Azam, F. (1980). Bacterioplankton secondary production estimates for coastal waters of British Columbia, Antarctica and California. Appl. environ. Microbiol 39: 1085-1095

Fuhrman, J. A., McManus, B. (1984). Do bacteria-sized marine eucaryotes consume significant bacterial production? Science 224: $1257-1260$

Graf, G. (1987). Benthic energy flow during a simulated autumn bloom sedimentation. Mar Ecol. Prog. Ser. 39: $23-29$

Groenendaal, M. M. (1975). Bacteriële sulfaatreduktie in de wadbodem. Netherlands Institute for Sea Research unpubl. report, 1975-15: 1-32

Hansen, J. A., A.longi, D. A., Moriarty, D. J. W., Pollard, P. C. (1987). The dynamics of benthic microbial communities at Davies Reef, central Great Barrier Reef. Coral Reefs 6: $63-70$

Helder, W., Bakker, J. F. (1985). Shipboard comparison of micro and mini oxygen electrodes or measuring oxygen distribution in marine sediments. Limnol Oceanogr 30: $1106-1109$

Hobbie, J. E., Daley, R. J., Jasper, S. (1977). Use of Nuclepore filters for counting bacteria by fluorescence microscopy. Appl. environ. Microbiol. 33: 1225-1228

Holm-Hansen, O., Lorenzen, C. J., Holmes, R. W., Strickland, J. D. H. (1965). Fluorometric determination of chlorophyll. J. Cons perm. int. Explor. Mer 30: 3-15

Kemp, P. F. (1987). Potential impact on bacteria of grazing by a macrofaunal deposit-feeder, and the fate of bacterial production. Mar Ecol. Prog. Ser. 36: 151-161

Kirchman, D. K., Ducklow, H., Mitchell, R. (1982). Estimates of bacterial growth from changes in uptake rates and biomass. Appl. environ. Microbiol. 44: 1296-1307

Kirchman, D. L., Hoch, M. P. (1988). Bacterial production in the Delaware Bay estuary estimated from thymidine and leucine incorporation rates. Mar Ecol. Prog. Ser 45 $169-178$

Lindeboom, H. J., Sandee, A. J. J. (1984). The effect of coastal engineering projects on microgradients and mineralisation reactions in sediments. Water Sci Technol. 16: 87-94

Malone, T C., Kemp, W. M., Ducklow, H. W., Boynton, W. R., Tuttle, J. H., Jonas, R. B. (1986). Lateral variation in the production and fate of phytoplankton in a partially stratified estuary. Mar. Ecol. Prog. Ser 32: 149-160

Mann, K. H. (1982\}. Ecology of coastal waters. A systems approach. Studies in Ecology 8. Blackwell Sclentific Publications, Oxford

Meyer-Reil, L.-A. (1983). Benthic response to sedimentation events during autumn to spring at a shallow water station in the western Kiel Bight. II. Analysis of benthic bacterial populations. Mar Biol. 77: 247-256

Meyer-Reil, L. -A. (1984). Bacterial biomass and heterotrophic activity in sediments and overlying waters. In: Hobbie, J. E., Williams, P. J. LeB. (eds.) Heterotrophic activity in the sea. NATO Conference Series. Series IV Marine Sciences, Plenum Press, New York, p. 532-546

Meyer-Reil, L.-A. (1987). Seasonal and spatial distribution of extracellular enzymatic activities and microbial incorporation of dissolved organic substrates in marine sediments. Appl. environ. Microbiol. 53: 1748-1755

Meyer-Reil, L.-A., Bölter, Mf, Dawson, R., Liebezeit, G., Szwerinskj, H., Wolter, K. (1980). Interrelationships between microbiological and chemical parameters of sandy beach sediments, a summer aspect. Appl. environ. Microbiol. 39: 797-802

Montagna, P. A., Bauer, J. E. (1988). Partitioning radiolabeled thymidine uptake by bacteria and meiofauna using metabolic blocks and poisons in benthic feeding studies. Mar Biol. 98: 101-110

Moriarty, D. J. W. (1982) Bacterial biomass and productivity in sediments, stromatolites, and water of Hamelin Pool, Shark Bay, western Australia. Geomicrobiol. J. 3: 121-133

Moriarty, D. J. W. (1984). Measurements of bacterial growth rates in some marine systems using the incorporation of tritiated thymidine into DNA. In: Hobbie, J. E., Williams, P. J. LeB. (eds.) Heterotrophic activity in the sea. NATO Conference Series. Series IV Marine Sciences, Plenum Press, New York, p. 217-231

Moriarty, D. J. W (1986) Measurement of bacterial growth rates in aquatic systems from rates of nucleic acid synthesis. In: Marshall, K. C. (ed.) Advances in microbial ecology, Vol. 9. Plenum Publ. Corp., New York, p. 245-292

Moriarty, D. J. W. (1988). Accurate conversion factors for calculating bacterial growth rates from thymidine incorporation into DNA: elusive or illusive? Arch. Hydrobiol. Beih Ergebn. Limnol. 31. 211-217

Moriarty, D. J. W. (1990). Techniques for estimating bacterial growth rates and production of biomass in aquatic environments. In: Norris, J. K., Grigorova, R. (eds.) Methods in microbiology, Vol. 22. Academic Press, London (in press)

Moriarty, D. J. W., Boon, P. I., Hansen, J. A., Hunt, W G. Poiner, I. R., Pollard, P. C., Skyring, G. W., White, D. C (1984). Microbial biomass and productivity in seagrass beds Geomicrobiol. J. 4: 21-51

Moriarty, D. J. W., Pollard, P. C. (1981). DNA synthesis as a measure of bacterial productivity in seagrass sediments. Mar. Ecol. Prog. Ser 5: 151-156

Moriarty, D. J. W., Pollard, P. C. (1982). Diel variation of bacterial productivity in seagrass (Zostera capricorni) beds measured by rate of thymidine incorporation into DNA Mar. Biol. 72: 165-173

Moriarty, D. J. W., Pollard, P. C., Hunt, W. G., Moriarty, C. M. Wassenberg, T J. (1985b). Productivity of bacteria and microalgae and the effect of grazing by holothurians in sediments on a coral reef flat. Mar Ecol. Prog. Ser 85 293-300

Moriarty, D. J. W., White, D. C., Wassenberg, T J. (1985a). A convenient method for measuring rates of phospholipid synthesis in seawater and sediments: its relevance to the determination of bacterial productivity and the disturbance artifacts introduced by measurements. J. microbiol Meth. 3: 321-330 
Newell, S. Y, Fallon, R. D. (1982). Bacterial productivity in the watercolumn and sediments of the Georgia (USA) coastal zone: estimates via direct counting and parallel measurements of thymidine incorporation. Microb. Ecol. 8: 33-46

Pollard, P. C., Moriarty, D. J. W. (1984). Validity of the tritiated thymidine method for estimating bacterial growth rates: the measurement of isotope dilution during DNA synthesis. Appl. environ. Microbiol. 48: 1076-1083

Postma, H. (1954). Hydrography of the Dutch Wadden Sea. Archs néerl. Zool. 10: 405-511

Postma, H. (1982). Hydrography of the Wadden Sea: movements and properties of water and particulate matter. Reports of the Wadden Sea Working Group. Balkema, Rotterdam, Report 2

Postma, H., Rommets, J. W (1970). Primary production in the Wadden Sea. Neth. J. Sea Res. 4: 470-493

Revsbech, N. P., Jørgensen, B. B. (1986). Microelectrodes: their use in microbial ecology. In: Marshall, K. C. (ed.) Advances in microbial ecology Vol. 9. Plenum, New York, p. 293-352

Strickland, J. D. H., Parsons, T R. (1972). A practical handbook of seawater analysis. Bull. Fish. Res. Bd Can. 167

Tobin, R. S., Anthony, D. H. J. (1978). Tritiated thymidine incorporation as a measure of microbial activity in lake sediments. Limnol. Oceanogr 23: 161-165

This article was submitted to the editor
Veldhuis, M. J. W., Colijn, F., Venekamp, L. A. H., Villerius, L. (1988). Phytoplankton primary production and biomass in the western Wadden Sea (The Netherlands); validation of an ecosystem model. Neth. J. Sea Res. 22: 23--36

Velji, M. I., Albright, L. J. (1986). Microscopic enumeration of attached marine bacteria of seawater, marine sediment, fecal matter, and kelp blade samples following pyrophosphate and ultrasound treatments. Can. J. Microbiol. 32: $121-126$

Vosjan, J. H., Olańczuk-Neyman, K. M. (1977). Vertical distribution of mineralization processes in a tidal sediment. Neth. J. Sea Res. 11: 14-23

Wilde, P. A. W J. de, Beukema, J. J. (1984). The role of zoobenthos in the consumption of organic matter in the Dutch Wadden Sea. In: Laane, R. W. P. M., Wolff, W. J. (eds.) The role of organic matter in the Wadden Sea. Neth. Inst. Sea Res. Publ. Ser. 10, Texel, p. 145-158

Wolff, W. J. (1983). Ecology of the Wadden Sea. Reports of the Wadden Sea Working Group. Balkema, Rotterdam, Vols. $1-3$

Zimmermann, R., Iturriaga R., Becker-Birk, J. (1978). Simultaneous determination of the total number of aquatic bacteria and the number thereof involved in respiration. Appl. environ. Microbiol. 36: 926-935

Manuscript first received: March 31, 1989

Revised version accepted: October 16, 1989 